\title{
Voluntary exercise increases cholesterol efflux but not macrophage reverse cholesterol transport in vivo in mice
}

\author{
Maxi Meissner ${ }^{+1}$, Niels Nijstad ${ }^{+1}$, Folkert Kuipers ${ }^{1,2}$ and Uwe JF Tietge*1
}

\begin{abstract}
Physical exercise beneficially impacts on the plasma lipoprotein profile as well as on the incidence of cardiovascular events and is therefore recommended in primary and secondary prevention strategies against atherosclerotic cardiovascular disease. However, the underlying mechanisms of the protective effect of exercise remain largely unknown. Therefore, the present study tested the hypothesis that voluntary exercise in mice impacts on cholesterol efflux and in vivo reverse cholesterol transport (RCT). After two weeks of voluntary wheel running (average $10.1 \pm 1.4$ $\mathrm{km} /$ day) plasma triglycerides were lower $(p<0.05)$, while otherwise lipid and lipoprotein levels did not change. Macrophage cholesterol efflux towards plasma was significantly increased in running $(n=8)$ compared to sedentary ( $n$ =6) mice (14.93 \pm 1.40 vs. $12.33 \pm 2.60 \%, p<0.05)$. In addition, fecal excretion of bile acids ( $3.86 \pm 0.50$ vs. $2.90 \pm 0.51$ $\mathrm{nmol} / \mathrm{d}, \mathrm{p}=0.001)$ and neutral sterols $(2.75 \pm 0.43 \mathrm{vs} .1 .94 \pm 0.22 \mathrm{nmol} / \mathrm{d}, \mathrm{p}<0.01)$ was significantly higher in running mice. However, RCT from macrophages to feces remained essentially unchanged in running mice compared with sedentary controls (bile acids: $3.2 \pm 1.0$ vs. $2.9 \pm 1.1 \%$ of injected dose, n.s.; neutral sterols: $1.4 \pm 0.7$ vs. $1.1 \pm 0.5 \%$ injected dose, n.s.). Judged by the plasma lathosterol to cholesterol ratio, endogenous cholesterol synthesis was increased in exercising mice $(0.15 \pm 0.03$ vs. $0.11 \pm 0.02, p<0.05)$, while the hepatic mRNA expression of key transporters for biliary cholesterol (Abcg5/g8, Sr-bl) as well as bile acid (Abcb11) and phospholipd (Abcb4) excretion did not change. These data indicate that the beneficial effects of exercise on cardiovascular health include increased cholesterol efflux, but do not extend to other components of RCT. The increased fecal cholesterol excretion observed in running mice is likely explained by higher endogenous cholesterol synthesis, however, it does not reflect increased $\mathrm{RCT}$ in the face of unchanged expression of key transporters for biliary sterol secretion.
\end{abstract}

\section{Introduction}

Complications of atherosclerotic cardiovascular disease (CVD) represent a major cause of morbidity and mortality in developed societies [1]. Physical exercise is associated with a reduced risk for coronary events and is therefore recommended for primary as well as secondary prevention strategies $[2,3]$. As one potential beneficial effect physical exercise has been shown to improve the plasma lipoprotein profile towards a less atherogenic phenotype [4,5]. In addition, exercise in humans increases the capacity of plasma to promote cholesterol

* Correspondence: u_tietge@yahoo.com

1 Department of Pediatrics, Center for Liver, Digestive and Metabolic Diseases, University Medical Center Groningen, University of Groningen, Groningen, The Netherlands

+ Contributed equally

Full list of author information is available at the end of the article efflux from RAW-264.7 mouse macrophages in vitro [6]. However, the impact of exercise on in vivo macrophageto-feces reverse cholesterol transport (RCT) has not been addressed. Therefore, the present study assessed the impact of voluntary exercise in mice on cholesterol efflux and in vivo RCT.

\section{Materials and methods \\ Animals}

Male C57BL/6J mice from Charles River (L'Arbresle, France) were kept in rooms with alternating 12-hour periods of light (from 7:00 a.m. to 7:00 p.m.) and dark (from 7:00 p.m. to 7:00 a.m.), with ad libitum access to water and mouse chow diet (Arie Blok, Woerden, The Netherlands). Animal experiments were performed in accordance with national laws and were approved by the 
responsible ethics committee of the University of Groningen.

\section{Voluntary cage wheel running experiments}

Twelve week old mice were individually housed in cages either equipped with an $11 \mathrm{~cm}$ steel running wheel continuously present in the cage (running group, $\mathrm{n}=8$ ) or not (sedentary control group, $n=6$ ) [7]. Distance covered and time of running were recorded daily during the two week experimental period with a digital cycling computer (K-13-TL SET-P3-NL, Xiron, The Netherlands).

\section{Cholesterol efflux and in vivo RCT}

Thioglycollate-elicited mouse peritoneal macrophages were harvested and cultured essentially as described [8]. Macrophages were loaded for $24 \mathrm{~h}$ with $50 \mu \mathrm{g} / \mathrm{ml}$ acetylated LDL and $3 \mu \mathrm{Ci} / \mathrm{ml}{ }^{3} \mathrm{H}$-cholesterol (Perkin Elmer, Boston, MA, USA) and equilibrated for $18 \mathrm{~h}$ in RPMI 1640 medium containing $1 \%$ penicillin/streptomycin and $2 \%$ bovine serum albumin (Sigma, St. Louis, MO, USA). For in vitro cholesterol efflux experiments, cells were incubated for $24 \mathrm{~h}$ with $1 \%$ of respective plasma samples (performed in triplicates). Efflux was determined as the percentage of label in the supernatant related to the total amount of label within medium and cells [9]. For in vivo RCT two million labeled macrophages were injected intraperitoneally, blood samples were taken at 6,24 and $48 \mathrm{~h}$, feces collected for $48 \mathrm{~h}$, and after $48 \mathrm{~h}$ livers were harvested (sacrifice by heart puncture under isoflurane anesthesia) and stored at $-80^{\circ} \mathrm{C}$ until further analysis as previously published [9]. Plasma counts were assessed directly by liquid scintillation counting (Packard 1600CA Tri-Carb, Packard, Meriden, CT, USA). Counts within liver were determined following solubilization of the tissue (Solvable, Packard, Meriden, CT, USA) exactly as reported [10]. Fecal samples were dried, weighed and thoroughly ground. Aliquots were separated into bile acid and neutral sterol fractions as previously published [11]. Counts recovered from respective aliquots were related to the total amount of feces produced over $48 \mathrm{~h}$. All obtained counts were expressed relative to the administered tracer dose.

\section{Plasma lipid and lipoprotein analysis}

Plasma total cholesterol and triglycerides were measured enzymatically (Wako Pure Chemical Industries, Neuss, Germany). To determine plasma HDL cholesterol levels, apoB-containing lipoproteins were precipitated using $0.36 \%$ phosphotungstic acid (Sigma) and cholesterol content in the supernatant was determined as described above. Pooled plasma samples from mice of the same experimental group were subjected to fast protein liquid chromatography (FPLC) gel filtration using a Superose 6 column (GE Healthcare, Uppsala, Sweden) as described
[10]. Samples were chromatographed at a flow rate of 0.5 $\mathrm{ml} / \mathrm{min}$, and fractions of $500 \mu \mathrm{l}$ each were collected. Individual fractions were assayed for cholesterol concentrations as described above. Plasma lathosterol levels relative to plasma cholesterol levels were measured by gas chromatography as described [12].

\section{Liver lipid analysis}

Liver lipids were extracted following the general procedure of Bligh and Dyer and were determined enzymatically using commercially available reagents (Wako Pure Chemical Industries, Neuss, Germany)[13].

\section{Analysis of gene expression by real-time quantitative PCR}

Total RNA from mouse livers was isolated using Trizol (Invitrogen), and real-time quantitative PCR was carried out on an ABI-Prism 7700 (Applied Biosystems, Foster City, CA, USA) sequence detector with the default settings [14]. PCR primers and fluorogenic probes were designed with the Primer Express Software (Applied Biosystems). mRNA expression levels were calculated relative to the average of the housekeeping gene cyclophilin and further normalized to the relative expression levels of the respective controls.

\section{Statistical analysis}

Statistical analysis was carried out using the Statistical Package for the Social Sciences (SPSS, Inc., Chicago, IL, USA). Values are expressed as means \pm SD. Student's $t$ test was used to assess statistical differences between groups. Statistical significance for all comparisons was assigned at $\mathrm{P}<0.05$.

\section{Results}

Voluntary exercise decreases hepatic cholesterol content, while plasma cholesterol levels remain unchanged

Exercising mice ran almost exclusively during the dark cycle, on average $356 \pm 52 \mathrm{~min} / \mathrm{d}$ thereby covering a distance of $10.2 \pm 2.2 \mathrm{~km}$ (average speed: $1.78 \pm 0.18 \mathrm{~km} / \mathrm{h}$ ). Plasma triglycerides were lower $(\mathrm{p}<0.05)$, while phospholipids, total, non-HDL and HDL cholesterol (table 1) and apoA-I (Western blot, data not shown) remained unchanged in response to exercise. FPLC analysis revealed a small decrease in the HDL and VLDL/LDL cholesterol peaks of running mice (Figure 1). Running increased liver weight by $12 \%(\mathrm{p}<0.01$, table 1$)$, while hepatic cholesterol and triglyceride contents were decreased by $14 \%(\mathrm{p}<0.05)$ and $42 \%(\mathrm{p}<0.001)$, respectively.

\section{Cholesterol efflux from macrophage foam cells towards plasma of running mice is increased}

Although plasma total cholesterol levels did not change and HDL cholesterol levels tended to be lower in running 
Table 1: Plasma and liver lipids in running C57BL/6 mice compared with sedentary controls

Sedentary $(n=6) \quad$ Running $(n=7)$

\begin{tabular}{|c|c|c|}
\hline \multicolumn{3}{|l|}{ PLASMA LIPIDS } \\
\hline Total cholesterol (mg/dl) & $85 \pm 3$ & $78 \pm 7$ \\
\hline HDL cholesterol (mg/dl) & $56 \pm 5$ & $49 \pm 6$ \\
\hline Non-HDL cholesterol (mg/dl) & $29 \pm 4$ & $29 \pm 6$ \\
\hline Triglycerides (mg/dl) & $68 \pm 20$ & $44 \pm 16^{*}$ \\
\hline Phospholipids (mg/dl) & $182 \pm 7$ & $155 \pm 23$ \\
\hline \multicolumn{3}{|l|}{ MORPHOLOGICAL DATA } \\
\hline Body weight (g) & $22.2 \pm 1.1$ & $21.8 \pm 1.3$ \\
\hline Liver weight (g) & $0.98 \pm 0.06$ & $1.1 \pm 0.06^{* *}$ \\
\hline $\begin{array}{l}\text { Liver weight (\% of body } \\
\text { weight) }\end{array}$ & $4.4 \pm 0.2$ & $5.0 \pm 0.3^{* *}$ \\
\hline Food intake (g/d) & $4.1 \pm 0.3$ & $5.4 \pm 0.5^{* * *}$ \\
\hline \multicolumn{3}{|l|}{ LIVER LIPIDS } \\
\hline Total cholesterol ( $\mu \mathrm{mol} / \mathrm{g})$ & $7.3 \pm 0.8$ & $6.3 \pm 0.7$ \\
\hline Free cholesterol $(\mu \mathrm{mol} / \mathrm{g})$ & $6.6 \pm 0.8$ & $5.6 \pm 0.7^{*}$ \\
\hline Cholesterol esters $(\mu \mathrm{mol} / \mathrm{g})$ & $0.7 \pm 0.3$ & $0.6 \pm 0.1$ \\
\hline Triglycerides ( $\mu \mathrm{mol} / \mathrm{g})$ & $24.3 \pm 3.6$ & $14.0 \pm 2.3^{* * *}$ \\
\hline Phospholipids ( $\mu \mathrm{mol} / \mathrm{g}$ ) & $37.8 \pm 5.5$ & $33.3 \pm 5.3$ \\
\hline
\end{tabular}

Values are means \pm SD determined after 2 weeks of voluntary wheel running exercise. Significant differences from sedentary mice are indicated as: ${ }^{*} \mathrm{p}<0.05 ;{ }^{* *} \mathrm{p}<0.01 ;{ }^{* * *} \mathrm{p}<0.001$.

mice, in vitro cholesterol efflux towards plasma of the running mice was significantly increased $(\mathrm{p}<0.001$, Figure 2). This effect was consistent independent of the blood sampling time from these mice, either directly after (a.m.) or before (p.m.) the running period.

\section{Macrophage-to-feces RCT is unchanged in exercising mice}

Next, in vivo RCT experiments were performed. ${ }^{3} \mathrm{H}$-cholesterol originating from macrophages was unchanged in plasma comparing running with sedentary mice as were counts within liver (Figure 3). Daily feces production (871 \pm 97 vs. $616 \pm 54 \mathrm{mg} / \mathrm{d}, \mathrm{p}<0.001)$ and mass fecal excretion of bile acids $(3.86 \pm 0.50 \mathrm{vs} .2 .90 \pm 0.51 \mathrm{nmol} / \mathrm{d}, \mathrm{p}=$ $0.001)$ and neutral sterols $(2.70 \pm 0.25$ vs. $1.90 \pm 0.39$ $\mathrm{nmol} / \mathrm{d}, \mathrm{p}<0.01$ ) were increased in the running group. However, fecal excretion of $3 \mathrm{H}$-cholesterol tracer originating from macrophages, reflecting completed RCT, remained unchanged both within neutral sterols and bile acids (Figure 3). In support of these physiological data, also the mRNA expression of several transporters critical for the biliary secretion of cholesterol (Abcg5/g8, Sr-bI), bile acids (Abcb11) and phospholipids (Abcb4) remained

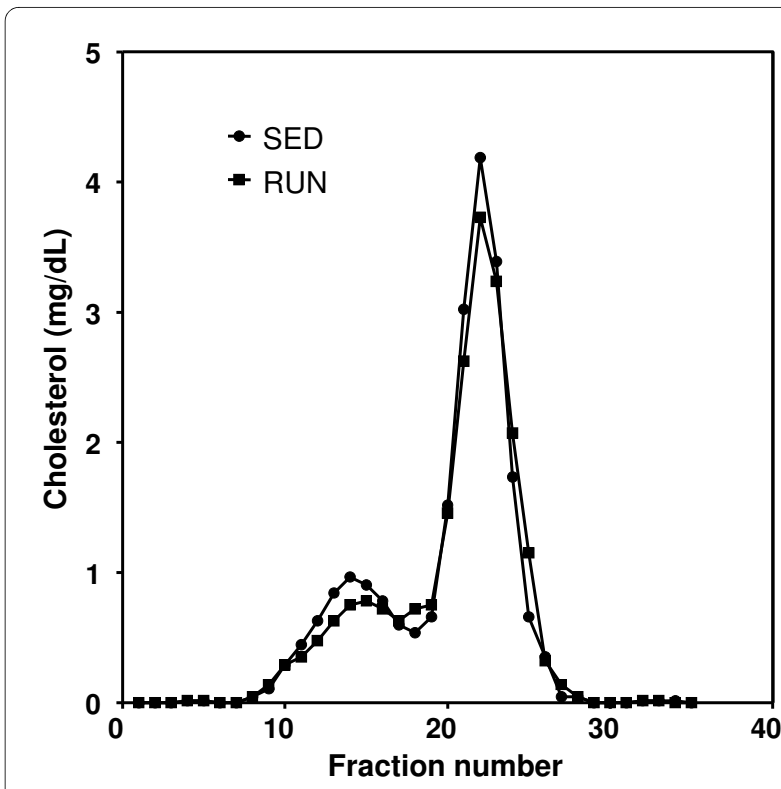

Figure 1 FPLC cholesterol profiles in sedentary (SED) and exercising mice (RUN). Pooled plasma samples were subjected to gel filtration using a superose 6 column and cholesterol levels within each fraction were determined as described in materials and methods.

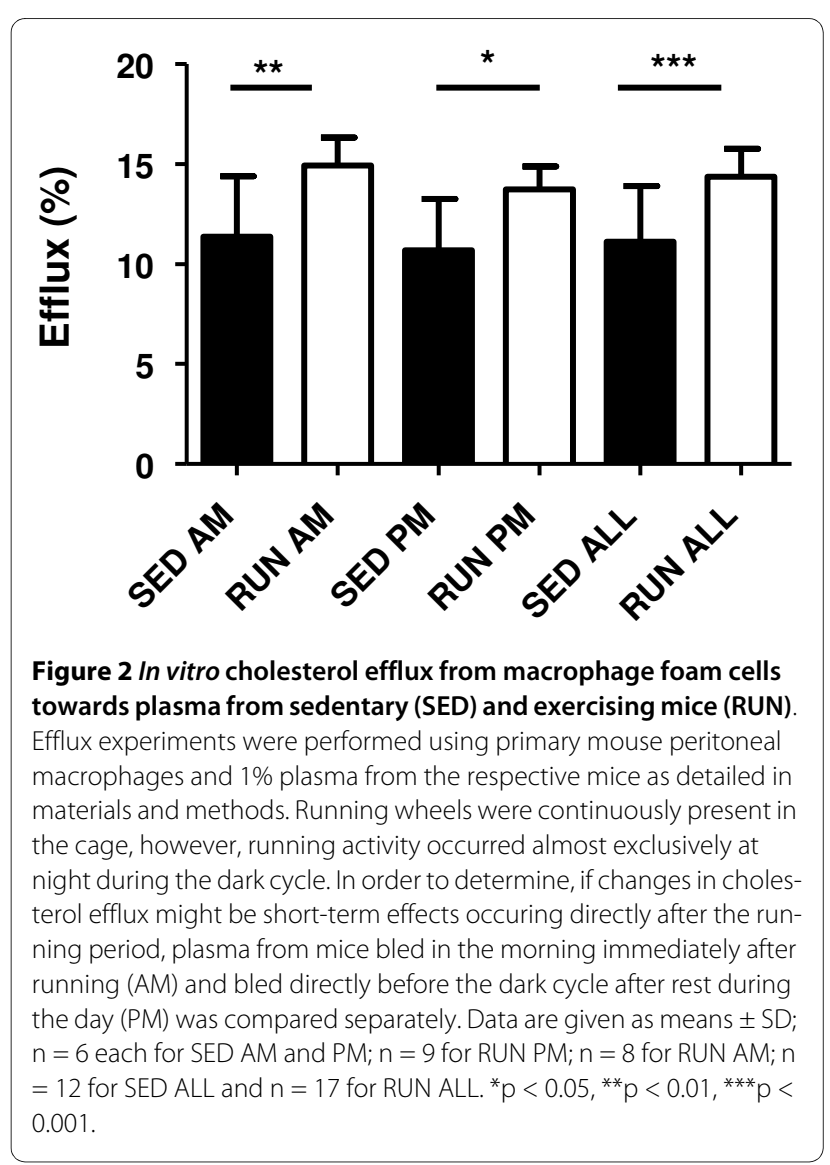




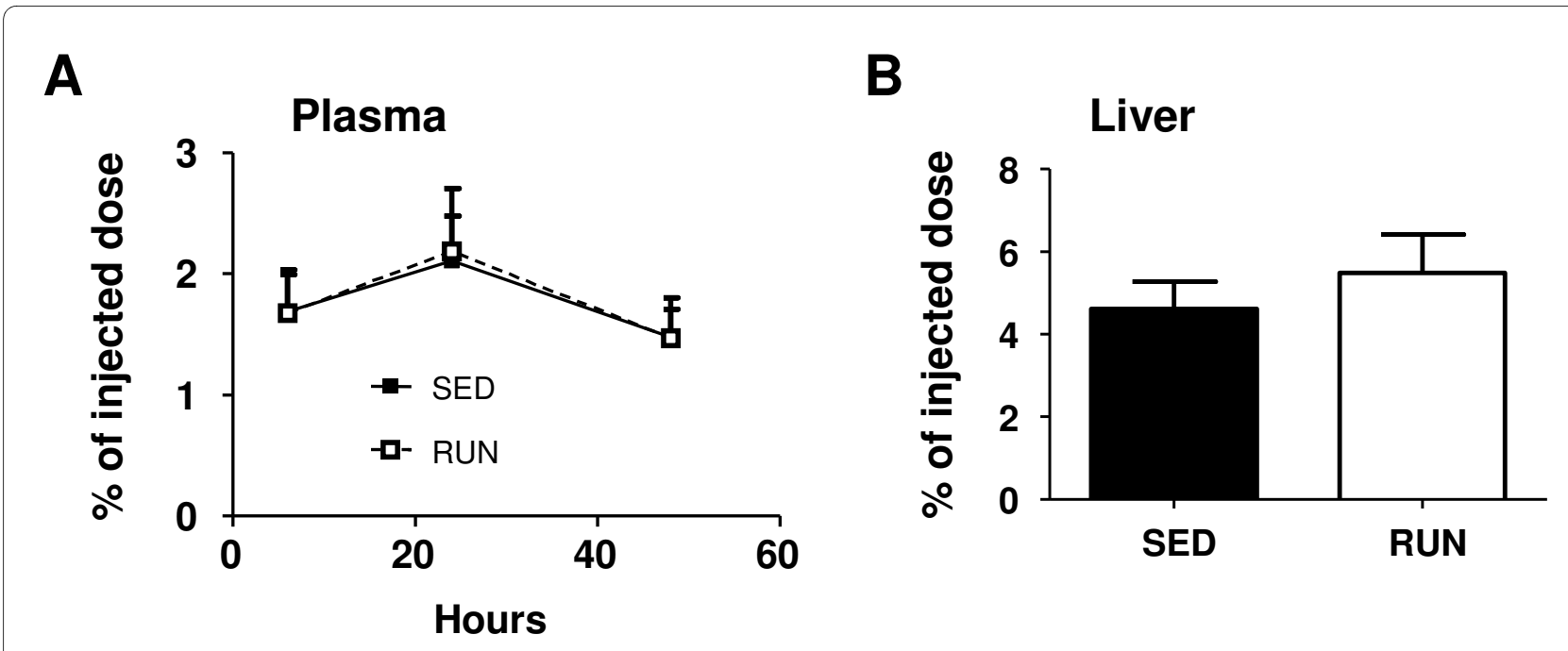

C

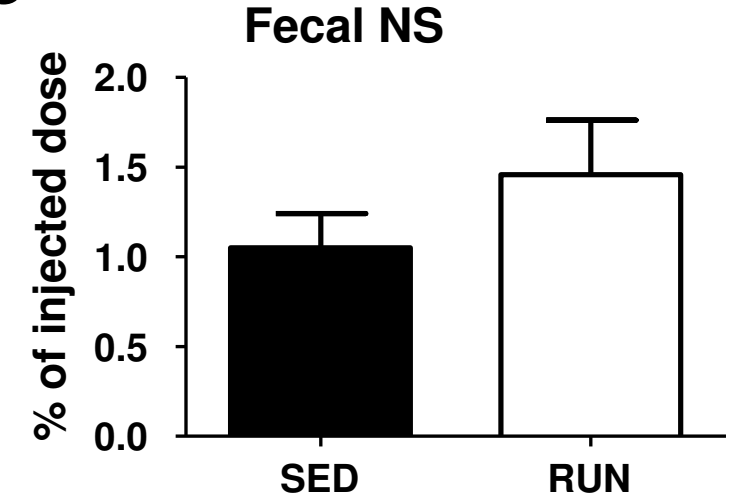

D

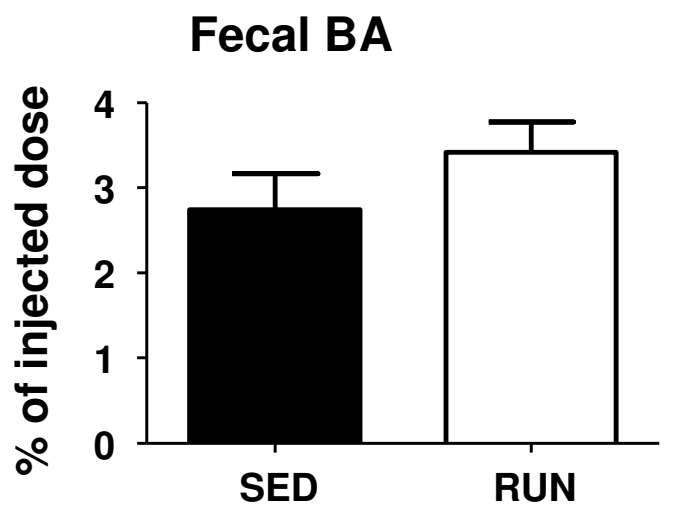

Figure 3 In vivo reverse cholesterol transport in sedentary (SED) and exercising (RUN) mice. At the end of the 2-week experimental period exercising mice $(n=8)$ and sedentary controls $(n=6)$ were injected intraperitoneally with ${ }^{3} \mathrm{H}$-cholesterol-labeled and acLDL-loaded primary mouse peritoneal macrophages and tracer appearance was followed for $48 \mathrm{~h}$ as detailed in materials and methods. (A) Time course of tracer appearance in plasma, (B) tracer recovery within liver at the $48 \mathrm{~h}$ time point, (C) tracer level within fecal bile acids (BA) after $48 \mathrm{~h}$, (D) tracer recovery within fecal neutral sterols (NS) after $48 \mathrm{~h}$. Data are expressed as percentage of the injected tracer dose and are given as means \pm SD.

unchanged (table 2). The plasma lathosterol/cholesterol ratio as a measure of endogenous cholesterol synthesis was significantly higher in the running mice (Figure 4) indicating that the increased amount of fecal sterols secreted in this group is rather originating from increased cholesterol synthesis than reflecting increased RCT.

\section{Discussion}

The results of this study demonstrate that voluntary exercise in mice increases the efflux capacity of plasma despite a tendency towards decreased plasma HDL cholesterol levels, but does not alter macrophage-to-feces RCT. To the best of our knowledge this is the first study investigating a potential impact of exercise on in vivo RCT. While the beneficial effects of exercise on cardiovascular health have long been noted and exercise has been implemented in the recommendations for primary as well as secondary prevention strategies [3], the precise underlying mechanism for exercise decreasing CVD risk has not been fully elucidated thus far. It has been noted that aerobic capacity training decreases markers of inflammation and oxidative stress as well as blood pressure levels over time [3,15-20], while acute endurance exercise such as marathon running is associated with increased oxidative stress and a pro-inflammatory response [21,22]. As a further beneficial effect of exercise in humans increased plasma HDL cholesterol levels and an increased capacity of plasma from exercising individuals to stimulate cholesterol efflux from macrophage foam cells in vitro has been noted [6]. These results have been related to an increased plasma level of pre $\beta$-HDL particles in trained individuals [23,24]. Our study confirmed 
Table 2: Hepatic gene expression levels in running C57BL/6 mice compared with sedentary controls

\begin{tabular}{lcc}
\hline & Sedentary $(\mathbf{n}=\mathbf{6})$ & Running $(\mathbf{n}=\mathbf{7})$ \\
\hline Abcg5 & $1.00 \pm 0.3$ & $1.2 \pm 0.3$ \\
Abcg8 & $1.00 \pm 0.2$ & $1.3 \pm 0.3$ \\
Sr-bl & $1.00 \pm 0.1$ & $1.0 \pm 0.2$ \\
Abcb11 & $1.00 \pm 0.1$ & $1.1 \pm 0.2$ \\
Abcb4 & $1.00 \pm 0.2$ & $1.1 \pm 0.2$ \\
\hline
\end{tabular}

mRNA expression levels were determined by real-time quantitative PCR in livers of C57BL/6 mice after 2 weeks of voluntary wheel running exercise compared with sedentary controls. Results are normalized to the expression of the housekeeping gene cyclophilin and are expressed relative to the respective controls. Data are given as means \pm SD.

the efflux data in a mouse model of voluntary endurance exercise, while in contrast to the human situation plasma HDL cholesterol levels rather had a tendency to be lower in exercising mice. The increase in cholesterol efflux in vitro was not reflected by altered plasma counts in the in vivo RCT experiment, likely since these represent the net balance between efflux and removal from the plasma compartment. Interestingly, feces production was increased in exercising mice, which also mirrors the human situation [25]. In addition, fecal mass secretion of bile acids and neutral sterols was significantly elevated in response to exercise, which in our interpretation reflects increased endogenous hepatic cholesterol synthesis. In humans one study reported a non-significant 63\% increase in endogenous cholesterol synthesis using the deuterium incorporation method [26], while another study detected no difference in plasma lathosterol levels in response to exercise training [27]. Since RCT in

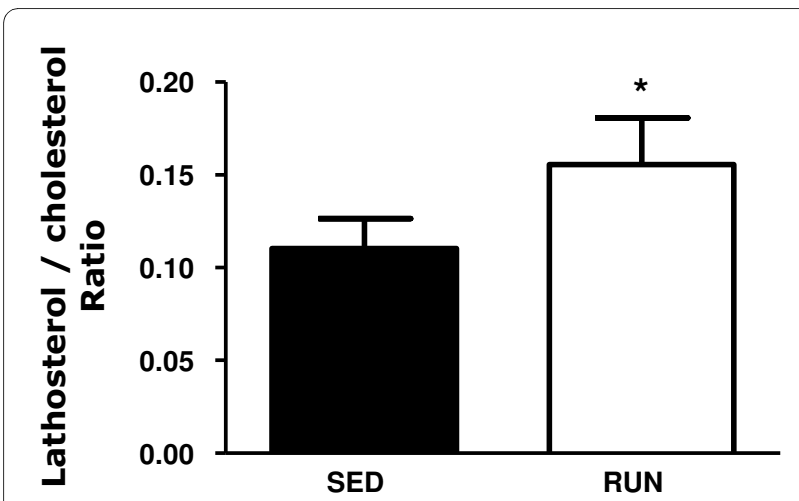

Figure 4 Effect of two week voluntary wheel running on the plasma lathosterol/cholesterol ratio as marker of endogenous cholesterol synthesis in exercising mice ( $R U N, n=8)$ and sedentary controls (SED, $\mathbf{n}=\mathbf{6}$ ). Plasma cholesterol and lathosterol levels were determined by gas chromatography as detailed in materials and methods. Data are given as means $\pm \mathrm{SD},{ }^{*} p<0.05$. humans differs in several aspects from mice (e.g. by the expression of CETP), studies on the impact of exercise on RCT in humans will be interesting to perform, once an integrated experimental system for these types of studies becomes available.

\section{Competing interests}

The authors declare that they have no competing interests.

\section{Authors' contributions}

MM and NN were involved in the acquisition and analysis of the data, participated in the design of the study and drafted the manuscript. FK contributed to interpretation of the data and critical revision of the manuscript. UJFT conceived of the study, participated in its design and coordination, and critically revised the manuscript. All authors read and approved the final manuscript.

\section{Acknowledgements}

This work was supported by grants from the Netherlands Organization for Scientific Research (NWO, VIDI Grant 917-56-358 to U.J.F.T.) and by GECKO (to F.K. and U.J.F.T.).

\section{Author Details}

1Department of Pediatrics, Center for Liver, Digestive and Metabolic Diseases, University Medical Center Groningen, University of Groningen, Groningen, The Netherlands and 2 Department of Laboratory Medicine, University Medical Center Groningen, University of Groningen, Groningen, The Netherlands

Received: 27 January 2010 Accepted: 1 July 2010

Published: 1 July 2010

\section{References}

1. Lloyd-Jones D, Adams R, Carnethon M, De Simone G, Ferguson TB, Flegal K, Ford E, Furie K, Go A, Greenlund K, Haase N, Hailpern S, Ho M, Howard V, Kissela B, Kittner S, Lackland D, Lisabeth L, Marelli A, McDermott M, Meigs J, Mozaffarian D, Nichol G, O'Donnell C, Roger V, Rosamond W, Sacco R, Sorlie P, Stafford R, Steinberger J, et al:: Heart disease and stroke statistics--2009 update: a report from the American Heart Association Statistics Committee and Stroke Statistics Subcommittee. Circulation 2009, 119:480-486.

2. Deedwania P, Kosiborod M, Barrett E, Ceriello A, Isley W, Mazzone T, Raskin P: Hyperglycemia and acute coronary syndrome: a scientific statement from the American Heart Association Diabetes Committee of the Council on Nutrition Physical Activity and Metabolism. Anesthesiology 2008, 109:14-24

3. Thompson PD, Buchner D, Pina IL, Balady GJ, Williams MA, Marcus BH, Berra K, Blair SN, Costa F, Franklin B, Fletcher GF, Gordon NF, Pate RR, Rodriguez BL, Yancey AK, Wenger NK: Exercise and physical activity in the prevention and treatment of atherosclerotic cardiovascular disease: a statement from the Council on Clinical Cardiology (Subcommittee on Exercise Rehabilitation, and Prevention) and the Council on Nutrition Physical Activity and Metabolism (Subcommittee on Physical Activity). Circulation 2003, 107:3109-3116.

4. Leon AS, Sanchez OA: Response of blood lipids to exercise training alone or combined with dietary intervention. Med Sci Sports Exerc 2001, 33:S502-S515.

5. Leon AS, Rice T, Mandel S, Despres JP, Bergeron J, Gagnon J, Rao DC, Skinner JS, Wilmore JH, Bouchard C: Blood lipid response to 20 weeks of supervised exercise in a large biracial population: the HERITAGE Family Study. Metabolism 2000, 49:513-520.

6. Olchawa B, Kingwell BA, Hoang A, Schneider L, Miyazaki O, Nestel P, Sviridov D: Physical fitness and reverse cholesterol transport. Arterioscler Thromb Vasc Biol 2004, 24:1087-1091.

7. Allen DL, Harrison BC, Maass A, Bell ML, Byrnes WC, Leinwand LA: Cardiac and skeletal muscle adaptations to voluntary wheel running in the mouse. J Appl Physiol 2001, 90:1900-1908.

8. Tietge UJF, Pratico D, Ding T, Funk CD, Hildebrand RB, Van Berkel T, Van Eck M: Macrophage-specific expression of group IIA sPLA2 results in accelerated atherogenesis by increasing oxidative stress. $J$ Lipid Res 2005, 46:1604-1614 
9. Annema W, Nijstad N, Tolle M, de Boer JF, Buijs RV, Heeringa P, van der Giet M, Tietge UJF: Myeloperoxidase and serum amyloid $A$ contribute to impaired in vivo reverse cholesterol transport during the acute phase response but not group IIA secretory phospholipase A2. J Lipid Res 2010, 51:743-754.

10. Nijstad N, Wiersma H, Gautier T, van der Giet M, Maugeais C, Tietge UJF: Scavenger receptor BI-mediated selective uptake is required for the remodeling of high density lipoprotein by endothelial lipase. J Biol Chem 2009, 284:6093-6100.

11. Wiersma H, Gatti A, Nijstad N, Kuipers F, Tietge UJF: Hepatic SR-BI but not endothelial lipase (EL) expression determines biliary cholesterol secretion in mice. J Lipid Res 2009, 50:1571-1580.

12. Windler E, Zyriax BC, Kuipers F, Linseisen J, Boeing H: Association of plasma phytosterol concentrations with incident coronary heart disease Data from the CORA study a case-control study of coronary artery disease in women. Atherosclerosis 2009, 203:284-290.

13. Wiersma H, Gatti A, Nijstad N, Oude Elferink RP, Kuipers F, Tietge UJF: Scavenger receptor class $B$ type I mediates biliary cholesterol secretion independent of ATP-binding cassette transporter g5/g8 in mice. Hepatology 2009, 50:1263-1272.

14. Wiersma H, Nijstad N, Gautier T, lqbal J, Kuipers F, Hussain MM, Tietge UJF: Scavenger receptor BI (SR-BI) facilitates hepatic very low density lipoprotein (VLDL) production in mice. J Lipid Res 2010, 51:544-553.

15. Cornelissen VA, Fagard RH: Effects of endurance training on blood pressure blood pressure-regulating mechanisms and cardiovascular risk factors. Hypertension 2005, 46:667-675.

16. Starnes JW, Barnes BD, Olsen ME: Exercise training decreases rat heart mitochondria free radical generation but does not prevent $\mathrm{Ca} 2+-$ induced dysfunction. J App/ Physio/ 2007, 102:1793-1798

17. Mota MR, Pardono E, Lima LC, Arsa G, Bottaro M, Campbell CS, Simoes HG: Effects of treadmill running and resistance exercises on lowering blood pressure during the daily work of hypertensive subjects. J Strength Cond Res 2009, 23:2331-2338.

18. Yung LM, Laher I, Yao X, Chen ZY, Huang Y, Leung FP: Exercise, vascular wall and cardiovascular diseases: an update (part 2). Sports Med 2009 39:45-63.

19. Schiffrin EL, Touyz RM: From bedside to bench to bedside: role of reninangiotensin-aldosterone system in remodeling of resistance arteries in hypertension. Am J Physiol Heart Circ Physiol 2004, 287:H435-H446.

20. Agarwal D, Haque M, Sriramula S, Mariappan N, Pariaut R, Francis J: Role of proinflammatory cytokines and redox homeostasis in exerciseinduced delayed progression of hypertension in spontaneously hypertensive rats. Hypertension 2009, 54:1393-1400.

21. Gomez-Cabrera MC, Martinez A, Santangelo G, Pallardo FV, Sastre J, Vina J: Oxidative stress in marathon runners: interest of antioxidant supplementation. Br J Nutr 2006, 96(Suppl 1):S31-S33.

22. Kratz A, Wood MJ, Siegel AJ, Hiers JR, Van Cott EM: Effects of marathon running on platelet activation markers : direct evidence for in vivo platelet activation. Am J Clin Pathol 2006, 125:296-300.

23. Jafari M, Leaf DA, Macrae H, Kasem J, O'conner P, Pullinger C, Malloy M Kane JP: The effects of physical exercise on plasma prebeta-1 highdensity lipoprotein. Metabolism 2003, 52:437-442.

24. Sviridov D, Kingwell B, Hoang A, Dart A, Nestel P: Single session exercise stimulates formation of pre beta 1-HDL in leg muscle. J Lipid Res 2003, 44:522-526.

25. Sutherland WH, Nye ER, Macfarlane DJ, Robertson MC, Williamson SA: Fecal bile acid concentration in distance runners. Int J Sports Med 1991, 12:533-536.

26. Varady KA, Houweling AH, Jones PJ: Effect of plant sterols and exercise training on cholesterol absorption and synthesis in previously sedentary hypercholesterolemic subjects. Trans/ Res 2007, 149:22-30.

27. Wilund KR, Feeney LA, Tomayko EJ, Weiss EP, Hagberg JM: Effects of endurance exercise training on markers of cholesterol absorption and synthesis. Physiol Res 2009, 58:545-552.

doi: $10.1186 / 1743-7075-7-54$

Cite this article as: Meissner et al., Voluntary exercise increases cholesterol efflux but not macrophage reverse cholesterol transport in vivo in mice Nutrition \& Metabolism 2010, 7:54

\section{Submit your next manuscript to BioMed Central} and take full advantage of:

- Convenient online submission

- Thorough peer review

- No space constraints or color figure charges

- Immediate publication on acceptance

- Inclusion in PubMed, CAS, Scopus and Google Scholar

- Research which is freely available for redistribution 